\title{
LAPOR HENDI : JEMBATAN PENGADUAN YANG SETENGAH HATI
}

Fiki Dzakiyati ${ }^{1}$, Rosihan Widi Nugroho ${ }^{2}$, Hardi Warsono ${ }^{3}$

\begin{abstract}
Abstrak
Lapor Hendi adalah layanan publik berbasis online untuk menyampaikan pengaduan, menyampaikan aspirasi dan berkomunikasi langsung dengan Pemkot Semarang. Inovasi ini menjadi sarana perbaikan layanan publik melalui peran aktif masyarakat dalam melakukan pengawasan. Penelitian ini bertujuan untuk mengevaluasi pengelolaan pelayanan pengaduan Lapor Hendi serta faktor penghambat dalam layanan Lapor Hendi. Menggunakan metode deskriptif kualitatif dengan studi kasus, pengambilan data melalui studi pustaka dan wawancara. Penelitian ini menggunakan teori William Dunn, 6 faktor dalam melalkukan evaluasi : efektivitas, efisiensi, kecukupan, perataan, responsivitas dan ketepatan serta faktor penghambat dalam pelaksanaan kebijakan. Dalam kajian ditemukan ada 2 faktor utama yang menghambat Lapor Hendi yaitu Sumbar Daya Manusia (SDM) dan Teknologi. Untuk meningkatkan penyelesaikan pengaduan diperlukan SOP sebagai panduan layanan, bukti bahwa pengaduan telah diselesaikan dan kontak penanggung jawab jika masyarakat melakukan konfirmasi terhadap pengaduan.
\end{abstract}

Kata kunci : Evaluasi, Kebijakan, Lapor Hendi

\section{PENDAHULUAN}

Transisi reformatif yang bergulir sejak dimulai tahun 1998 hingga saat ini, bersamaan dengan arus globalisasi memberikan peluang sekaligus tantangan bagi perbaikan tata pemerintahan dan tata bernegara. Perubahan besar tersebut mendorong pemerintah untuk kembali memahami arti pentingnya suatu kualitas pelayanan untuk publik serta pentingnya dilakukan perbaikan mutu pelayanan publik. Perbaikan kualitas pelayanan pemerintah untuk publik senantiasa menjadi tuntutan. Dalam perkembangan terkini, disuatu era transisi dengan rakyat yang mencitakan kehidupan yang lebih demokratik fungsi pemberian pelayanan publik telah menjadi arus utama dimana-mana, teramati sebagai gelombang peradaban dunia. Pemerintahan dengan segenap jajarannya

\footnotetext{
${ }^{1}$ Mahasiswa Program Studi Magister Ilmu Administrasi, Departemen Administrasi Publik, FISIP, Universitas Diponegoro Semarang.

${ }^{2}$ Mahasiswa Program Studi Magister IImu Administrasi, Departemen Administrasi Publik, FISIP, Universitas Diponegoro Semarang.

${ }^{3}$ Dosen Program Studi Magister IImu Administrasi, Departemen Administrasi Publik, FISIP, Universitas Diponegoro Semarang.
} 
dalam kebijakan dan penyediaan pelayanan publik dituntut untuk selalu menghormati hak-hak asasi rakyat, dan tanggap untuk memenuhi kebutuhan dan kepentingan warga publik. $^{4}$

Ditengah perkembangan yang seperti ini, siapapun yang mengemban tugas pemerintahan mesti menyadari sepenuhnya norma pemerintahan, bahwa kewenangan yang melekat pada instansi birokrasi pemerintahan itu sesungguhnya bersumber dari suara rakyat yang diberikan semasa penyelenggaraan pemilihan umum. Proses ini merupakan langkah paradigmatik yang menjadikan rakyat sebagai "sang penerima pelayanan" dengan jajaran birokrasi sebagai "sang pelayan". Konsepsi ini telah mengubah secara besar-besaran konsepsi klasik dan tradisional tentang status kelembagaan pemerintahan, sejalan dengan derap langkah modernisasi dan reformasi birokrasi pada takaran demokratisasi sebagai spirit birokrasi, yang terus bermetamorfosis sejalan dengan "arah zaman". 5

Mandat pasal 36 dan pasal 37 UU No25 Tahun 2009 tentang Pelayanan Publik, diwajibkan bagi penyelenggara pelayanan publik untuk menyediakan sarana pengaduan dan menugaskan pelaksana yang kompeten dalam pengelolaan pengaduan. Sebagai tindak lanjut dari peraturan tersebut, Pemerintah menerbitkan Perpres No 76 Tahun 2013 tentang Pengelolaan Pengaduan Pelayanan Publik Secara Nasional yang kemudian ditindaklanjuti oleh Peraturan Menteri Pendayagunaan Aparatur Negara dan Reformasi Birokrasi Republik Indonesia Nomor 24 Tahun 2014 tentang Pedoman Penyelenggaraan Pengelolaan Pengaduan Pelayanan Publik Secara Nasional. Adanya Perpres dan Permen ini dalam rangka upaya peningkatan kualitas pelayanan publik melalui pengelolaan pengaduan masyarakat agar masyarakat memperoleh pelayanan publik yang berkualitas, wajar, dan adil.

Dalam konteks layanan pengaduan, peran partisipasi masyarakat menjadi penting. Baik buruknya layanan ini sangat berpengaruh terhadap kepercayaan terhadap pemerintah. Untuk itu Pemerintah Kota Semarang membuat layanan pengaduan Lapor Hendi. Lapor Hendi merupakan bagian dari LAPOR, system pengelolaan pengaduan yang dikembangkan UKP4/ Unit Kerja Presiden bidang Pengawasan Pengendalian Pembangunan, sejak tahun 2011. Melalui Lapor Hendi masyarakat bias melakukan

${ }^{4}$ Haryono, Yudhie (2008) Mental Kolonialisme hal 45

${ }^{5}$ Haryono, Yudhie (2008) Mental Kolonialisme hal 67 
pengaduan, menyampaikan aspirasi dan berkomunikasi langsung dengan Pemkot Semarang.

Lapor Hendi Melalui website laporhendi.semarangkota.go.id/. Masyarakat dapat mengirim pengaduan melalui website tersebut dengan membuat akun, atau dapat melalui sms ke nomor 1708 dengan format "Laporhendi" spasi aduan atau melalui Twitter caranya dengan tweet aduan_anda kemudian tambahkan \#LaporHendi dan dimention ke @PemkotSMG. Selain itu aplikasi ini dapat diunduh bagi pengguna android dan IOS. Laporan yang telah tervalidasi di dalam LAPOR! Lalu didisposisikan ke kementerian/ Lembaga/ Pemerintah Daerah yang sesuai kemudian ditindaklanjuti sesuai dengan ketentuan yang ada. Dasar layanan Lapor Hendi melalui Perwal no 34 tahun 2017 tentang pedoman pengelolaan pengaduan masyarakat tentang pelayanan publik.

Hasil penelitian awal kami, menemukan fakta yang tidak sesuai dengan harapan kebijakan aplikasi ini. bahwa tidak semua warga kota Semarang mengetahui dan menggunakan aplikasi ini. Sebanyak $27.8 \%$ responden kami menyatakan tidak mengetahui aplikasi ini dan sebanyak $85.6 \%$ responden menyatakan kecewa karena tidak ada tindak lanjut atau kepastian jawaban atas aduan yang mereka layangkan lewat aplikasi Lapor Hendi ini. Lebih lanjut $85.4 \%$ menyatakan bahwa yang menjawab aduan mereka di aplikasi ini adalah sistem mesin.

Hal ini senada dengan temuan Pattiro (2017), yang menemukan fakta yang tidak sesuai dengan harapan layanan. Tahun 2017 Pattiro (2017) melakukan uji pengaduan terhadap layanan Lapor Hendi Pemkot Semarang. Uji pengaduan adalah proses melakukan pengaduan persoalan - persoalan nyata dimasyarakat secara langsung untuk mengetahui layanan tersebut sesuai dengan peraturan atau belum. ${ }^{6}$ Uji ini dilakukan dengan melalui 21 pengaduan yang dikirimkan yang terbagi menjadi tiga tipe pengaduan: Pertama, kategori ringan yang isinya terkait permohonan informasi. Kedua, kategori sedang yang isinya terkait aduan untuk sarana dan infrastruktur. Dan ketiga, kategori berat yang isinya terkait adanya indikasi penyelewengan dan pelanggaran oleh pemerintah.

${ }^{6}$ Pattiro Semarang (2017). Uji Pengaduan Pelayanan Pengolaaan Kota Semarang 2017. 
Pengaduan dilakukan melalui sarana prasara Lapor Hendi yaitu 1) Melalui SMS ke 1708, 2) Twitter dengan \#laporhendi; dan 3) Langsung ke loket P3M. Distribusi aduan menggunakan SMS ada 9 (Sembilan) aduan, menggunakan twitter ada 10(sepuluh) aduan, dan melalui Loket P3M ada 2 (dua) aduan. Dari hasil uji pengaduan, yang diterima oleh pihak terkait berjumlah 14 (empat belas) buah aduan, dan yang tidak diterima 7 (tujuh) aduan. Dari aduan yang diterima, 10 (sepuluh) aduan dijawab dari instansi terkait, sedangkan 4 (empat) aduan tidak mendapat jawaban. Dari jumlah aduan dijawab, yang ditindaklanjuti hanya ada 2 (dua) aduan.

Berdasarkan media, laporan aduan yang tidak diterima ada 2 (dua) yang menggunakan media SMS, 3 (tiga) dengan Twitter, dan 2 (dua) melalui Loket P3M. Sedangkan laporan aduan yang diterima, sejumlah 7 (tujuh) aduan melalui SMS, 7 (tujuh) aduan dengan Twitter. Menurut kategorinya, dari 10 (sepuluh) aduan yang dijawab, 3 (tiga) buah aduan mempunyai kategori berat, 5 (lima) aduan berkategori sedang, dan 2 (dua) aduan dengan kategori ringan. Waktu yang digunakan, sejak pengiriman aduan sampai mendapat jawaban berkisar antara 2-20 hari kerja.

Uji Pengaduan ini bertolak belakang dengan hasil penelitian dari Muzaki dan Manar (2017) yang mengemukakan kualitas maupun kuantitas sumber daya kebijakan Lapor Hendi dalam kondisi yang baik dan cukup memadai, baik dari sisi dukungan, kapasitas maupun nilai manfaat yang diperoleh. Adapun kekurangan yang terdapat pada sumber daya kebijakan ini, tahun 2018 sudah direncanakan mengenai solusinya berdasar kekurangan yang terjadi pada tahun $2017 .{ }^{7}$ Hal ini tentu sangat ironis, mengingat aplikasi Lapor Hendi ini telah mendapatkan penghargaan sebagai pelayanan publik Ombudsman RI dengan Predikat Kepatuhan Tinggi atau Zona Hijau. ${ }^{8}$

Tujuan dari penelitian ini yaitu untuk mengevaluasi pengelolaan pelayanan pengaduan Lapor Hendi dengan menggunakan 6 faktor evaluasi dari William N. Dunn yaitu efektivitas, efisiensi, kecukupan, perataan, responsivitas, ketepatan Serta untuk menganalisis faktor-faktor yang menghambat dalam penerapan aplikasi Lapor Hendi di Kota Semarang.

\footnotetext{
${ }^{7}$ Muzaki dan Manar (2017). Pengelolaan Lapor Hendi di Kota Semarang Tahun 2017, Kajian Sumber Daya Kebijakan. E-journal Undip.

${ }^{8}$ http://semarangkota.go.id/berita/read/pelayananpublikkotasemarangraihpredikatkepatuhantinggiomb udsmanRI
} 
Metode yang digunakan dalam penelitian ini yaitu studi kasus. Yakni mempelajari dan menganalisa terhadap suatu keadaan atau kejadian yang disebut sebagai kasus dengan menggunakan cara-cara yang sistematis. ${ }^{9}$ Sementara itu, yang menjadi fokus dalam penelitian ini yaitu : Faktor evaluasi menurut Dunn yaitu efektivitas, efisiensi, kecukupan, perataan, responsivitas, ketepatan. ${ }^{10}$ Serta fokus penelitian lainnya yaitu faktor penghambat dalam pelaksanaan aplikasi Lapor Hendi ini. Informan dalam penelitian ini ditentukan dengan menggunakan teknik purposive yaitu ditentukan dengan menyesuaikan pada tujuan penelitian atau tujuan tertentu. Teknik analisis data menggunakan Miles and Huberman dalam Sugiyono yaitu dalam proses pengumpulan data dilakukan tiga kegiatan penting, diantaranya: reduksi data, pengolahan data, penyajian data dan penarikan kesimpulan. ${ }^{11}$

\section{PEMBAHASAN}

\section{Evaluasi Pelayanan Pengelolaan Pengaduan Lapor Hendi}

Menurut William Dunn ada 6 faktor evaluasi yang digunakan dalam proses evaluasi kebijakan. Factor itu adalah efektivitas, efisiensi, kecukupan, perataan, responsivitas, ketepatan Serta untuk menganalisis faktor-faktor yang menghambat.

\section{$\underline{\text { Efektivitas }}$}

Efektivitas dapat dilihat dari apakah hasil yang diinginkan bias tercapai. Berdasarkan uji pelayanan pengaduan yang dilakukan Pattiro diketahui bahwa persentase aduan melalui program Lapor Hendi yang ditanggapi dengan tindak lanjut relatif kecil (hanya 9,5\%). Hal ini menunjukkan bahwa Lapor Hendi ini belum efektif untuk menindaklanjuti pengaduan yang dilakukan oleh masyarakat.

\footnotetext{
${ }^{9}$ Komariah, D. S. (2010). Metodologi Penelitian Kualitatif. Bandung: Alfabeta.

${ }^{10}$ William N Dunn (2005). Analisis Kebijakan Publik. Yogyakarta: Gajah Mada Press

${ }^{11}$ Sugiyono. (2009). Metode Penelitian Kuantitatif. Bandung: Alfabeta.
} 
Grafik 1. Persentase Tanggapan atas aduan Lapor Hendi

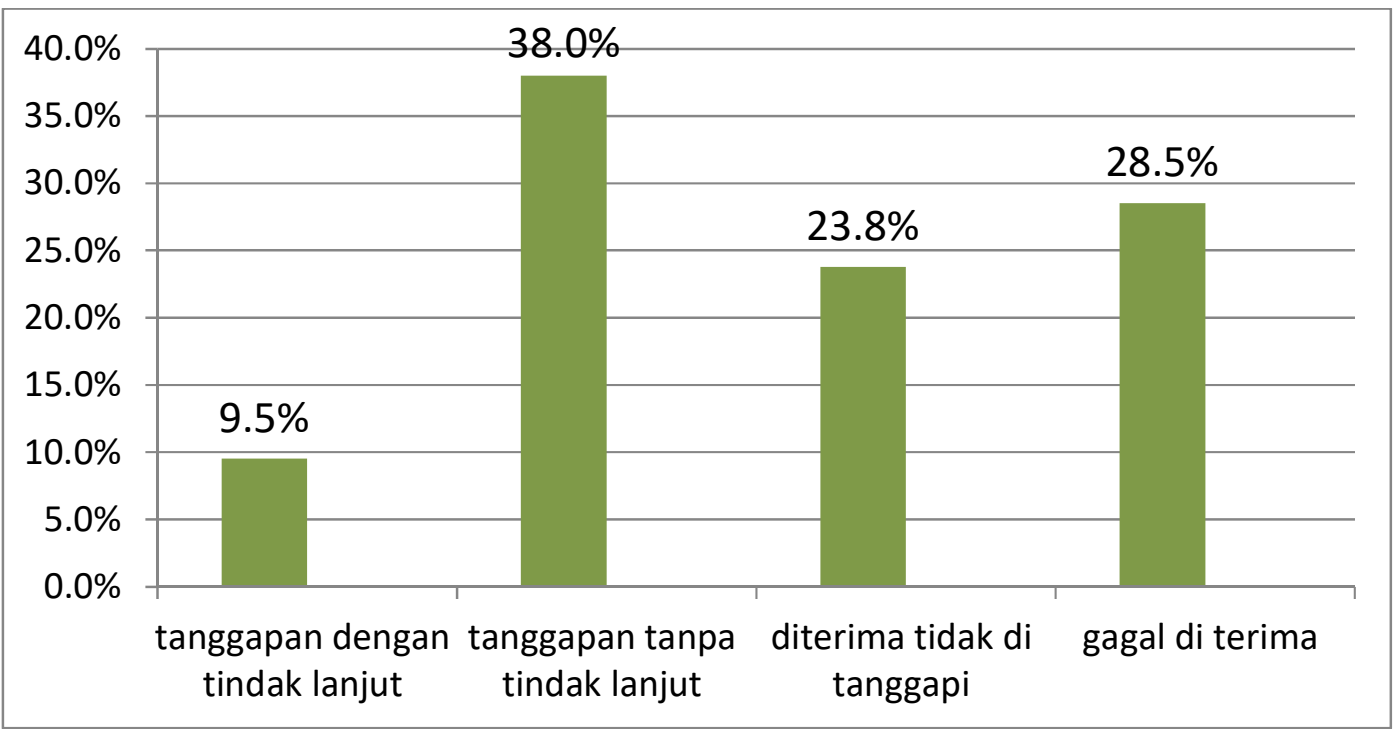

Sumber : (Pattiro, 2017)

Temuan peneliti, laporan yang ditindak lanjuti mendapatkan pengaduan melalui media social twitter, yang langsung di mention ke akun pribadinya Walikota Semarang secara langsung.

\section{$\underline{\text { Efisiensi }}$}

Efisiensi dilihat dari seberapa banyak usaha yang diperlukan untuk mencapai hasil yang diinginkan. ${ }^{12}$ Efisiensi lamanya waktu dalam proses pengajuan aduan tentu akan memberikan efek kerugian yakni kelelahan psikis dari pelapor, di sisi lain tingkat kepercayaan masyarakat akan layanan prima terhadap pengelolaan aduan pun berkurang.

Program Lapor Hendi memiliki alur yang dimulai dari input laporan, verifikasi laporan, disposisi laporan dan tindak lanjut laporan. ${ }^{13}$ Pada kasus aduan tentang PDAM yang mati selama sepuluh hari. Pelapor menyatakan bahwa ia harus berulang kali mengirimkan aduan Lapor Hendi via twitter dan baru ditanggapi setelah mention langsung kea kun twitter pribadi walikota.

Dari berbagai kasus yang di tanggapi dan ditindaklanjuti dapat dikatakan bahwa efisiensi program Lapor Hendi ini kurang, karena Pelapor harus berulangkali mengajukan laporan aduannya, bahkan tidak segan untuk melakukan tindakan cepat dengan mention langsung ke walikota atau melapor ke pejabat yang kebetulan dikenalnya.

\footnotetext{
${ }^{12}$ William N Dunn (2005). Analisis Kebijakan Publik. Yogyakarta: Gajah Mada Press

${ }^{13}$ http://p3msemarangkota.go.id.diakses 25 Oktober 2018
} 


\section{Kecukupan}

Kecukupan yang dimaksud di sini adalah seberapa jauh pencapaian hasil yang diinginankan memecahkan masalah. ${ }^{14} \mathrm{Pada}$ beberapa aduan yang hanya direspon dengan jawaban mesin, seperti aduan tentang kemacetan dan truk yang parker sembarangan.

Dari data yang didapatkan di P3M Kota Semarang bahwa pada dasarnya Pemkot Semarang serius dalam melakukan pengelolaan pelayanan pengaduan. Hal ini tampak dari dialokasikannya sejumlah sumber daya untuk pelaksanaan Lapor Hendi,. Banyaknya aduan dari masyarakat merupakan respon yang baik terhadap program ini. Namun tidak semua aduan bisa ditelan mentah-mentah, harus ada verifikasi tentang laporan, dan ini membutuhkan proses. Namun diupayakan bahwa tindak lanjut dari aduan ini bisa memecahkan masalah aduan yang dihadapi.

Dalam kasus kemacetan Silayur, data yang didapatkan adalah bahwa tindak lanjut belum memuaskan, karena hanya mengganti titik kemacetan, dari Silayur ke depan segitiga emas. Dari segi kecukupan, sebagai upaya untuk memecahkan maslah masyarakat dianalisis kurang.

\section{Perataan}

Perataan adalah apakah biaya manfaat didistribusikan dengan merata kepada kelompok-kelompok yang berbeda. ${ }^{15}$ Lapor Hendi memiliki dukungan insfratruktur yang memadai, seperti jaringan internet dan router, sumber daya manusia yang cukup dengan 66 admin penghubung dan 5 orang admin pusat serta ketersediaan sumber daya finansial yang mencukupi.

Temuan peneliti, tidak semua warga kota Semarang mengetahui dan menggunakan program ini. Sebanyak 27.8 \% responden kami menyatakan tidak mengetahui program ini. Dan sebanyak $85.6 \%$ responden menyatakan kecewa karena tidak ada tindak lanjut atau kepastian jawaban atas aduan yang mereka layangkan lewat Lapor Hendi ini. Lebih lanjut $85.4 \%$ menyatakan bahwa yang menjawab aduan mereka di program adalah sistem mesin. Dalam konteks perataan Pemkot Semarang sudah mempunyai sumber daya yang memadai untuk mendukung program Lapor Hendi.

\footnotetext{
${ }^{14}$ William N Dunn (2005). Analisis Kebijakan Publik. Yogyakarta: Gajah Mada Press

${ }^{15}$ William N Dunn (2005). Analisis Kebijakan Publik. Yogyakarta: Gajah Mada Press
} 


\section{$\underline{\text { Responsivitas }}$}

Responsivitas adalah apakah hasil kebijakan memuaskan kebutuhan, preferensi atau nilai kelompok-kelompok tertentu. ${ }^{16}$ Pelayanan pengaduan akan dianggap memuaskan jika ada tanggapan, atau respon dari aduan tersebut. ${ }^{17}$.

Hasil uji aduan yang dilakukan Pattiro menunjukkan bahwa ada 38\% aduan yang ditanggapi namun tidak ada tindak lanjut serta $23,8 \%$ aduan yang diterima namun tidak ditanggapi. ${ }^{18}$ Lebih lanjut, pada kasus aduan yang diterima, lamanya waktu proses tindak lanjut atas aduan membuat kepuasan pelapor melemah. Hasil penelitian didapatkan bahwa untuk tindak lanjut aduan kasus yang tergolong berat, ditindak lanjuti dalam waktu hampir satu bulan. Itupun setelah berlang kali malayangkan aduan. Maka dalam konteks responsivitas Pemkot Semarang belum memberikan layanan secara optimal.

\section{Ketepatan}

Ketepatan yang dimaksudkan adalah hasil yang diinginkan benar-benar berguna atau bernilai. ${ }^{19}$ Dalam pelaksanaannya, P3M Kota Semarang akan menindaklanjuti aduan dengan meneruskan ke SKPD yang bersangkutan dengan aduan tersebut. Atau dengan kata lain, adanya keterbatasan wewenang dari P3M untuk menindaklanjuti aduan secara langsung,

Keluhan dari Pelapor terkait lambannya respon serta tindak lanjut yang belum maksimal. Hal tersebut terjadi karena banyaknya yang menjalankan sistem tersebut sehingga sistem eror dan adanya proses atau alur untuk menindaklanjuti aduan tersebut. Di sisi lain, beberapa kasus tindak lanjut aduan yang tidak sesuai harapan, seperti aduan penguraian kemacetan di Silayur yang hanya memindahkan tempat macet. Berdasarkan hal tersebut, dari sisi ketepatan, program Lapor Hendi ini dinilai kurang.

Berdasarkan evaluasi di atas, dapat disimpulkan bahwa program Lapor Hendi adalah jembatan pengaduan yang setengah hati. Program ini memiliki visi dan tujuan yang bermanfaat dan baik, program ini juga sudah didukung oleh sarana infrastruktur yang memadai. Namun dalam pelaksanaannya, program ini belum maksimal. Beberapa kasus yang menunjukkan tidak diresponnya aduan dan kurang tindak lanjut membuktikan

\footnotetext{
${ }^{16}$ William N Dunn (2005). Analisis Kebijakan Publik. Yogyakarta: Gajah Mada Press

${ }^{17}$ Jamaludin Ancok (2009). Komunikasi Publik. Yogyakarta: Gajah Mada Press

${ }^{18}$ Pattiro Semarang (2017). Uji Pengaduan Pelayanan Pengolaaan Kota Semarang 2017.

${ }^{19}$ William N Dunn (2005). Analisis Kebijakan Publik. Yogyakarta: Gajah Mada Press
} 
bahwa dalam sumber daya dan infrastruktur sudah baik namun belum mendukung layanan Lapor Hendi.

\section{Faktor-faktor penghambat dalam Lapor Hendi}

Berdasarkan uraian di atas peneliti menyimpulkan bahwa program Lapor Hendi ini terlaksana kurang maksimal. Peneliti melakukan analisa terhadap faktor-faktor yang penghambat kurang optimalnya pelaksanaan program ini. Setiap inovasi dalam penerapan atau penggunaannya tidak terlepas dari berbagai hambatan, hal tersebut juga terjadi pada penerapan Lapor Hendi yang merupakan inovasi pelayanan pengaduan di Kota Semarang. Hasil wawancara dengan Pihak P3M Kota Semarang dan Masyarakat yang pernah menggunakan layanan Lapor Hendi diketahui bahwa ada dua faktor penghambat dalam penerapan Lapor Hendi, yaitu Sumber Daya Manusia dan teknologi.

Pertama, faktor Sumber daya manusia ini terfokus pada budaya kerja yang cenderung kurang sigap dan menunggu instruksi pimpinan. Hasil wawancara pada pelapor yang kasusnya ditindaklanjuti menunjukkan indikasi budaya menunggu instruksi pimpinan. Beberapa kasus aduan yang ditindaklanjuti adalah aduan dengan menggunakan media social twitter yang mention langsung ke Walikota. Di sisi lain, berdasarkan hasil wawancara dengan P3M Kota Semarang diketahui bahwa dalam penerapan Lapor Hendi masih terhambat oleh keterbatasan oleh hambatan administratif. Jumlah admin pusat hanya 5 orang sementara aduan yang masuk jumlahnya ribuan. Di sisi lain, aduan tersebut adalah wewenang SKPD yang bersangkutan untuk menindaklanjuti, ada proses menunggu disposisi tindak lanjut dan dipilih aduan yang sifatnya segera atau yang biasa. Banyaknya pekerjaan yang harus dilaksanakan dengan jumlah tenaga sumber daya manusia yang melaksanakan pekerjaan ini membuat perbandingan tidak sesuai.

Sumber daya manusia sebagai faktor yang mempengaruhi keberhasilan kinerja juga dikemukakan oleh Robins. Robins (2004) mengemukakan bahwa keberhasilan suatu kegiatan dalam organisasi sangat ditentukan oleh sumber daya manusianya. Sumber daya manusia ini mencakup kemampuan kerja dan budaya kerja dalam organisasi tersebut. ${ }^{20}$ Hal senada juga di kemukakan oleh Krisdanti dan Rodhiyah. Terdapat pengaruh yang

\footnotetext{
${ }^{20}$ Robins, Stephen P (2004). Perilaku Organisasi: Konsep, Kontroversi, Aplikasi, Jilid I, Edisi Bahasa Indonesia, Alih Bahasa: Handyana Pujaatmaka, PT. Prenhallindo, Jakarta.
} 
signifikan dan positif antara Sumber Daya Manusia dengan kinerja. ${ }^{21}$. Maka dapat disimpulkan bahwa sumber daya manusia merupakan faktor pendukung dan juga penghambat keberhasilan suat program. Menjadi Pendukung saat sumber daya manusia ini berperan sebagaimana yang diharapkan, sedangkan menjadi penghambat saat sumber daya manusia ini tidak sesuai dengan harapan. Pada Lapor Hendi, Sumber daya manusia menjadi faktor penghambat karena keterbatasannya.

Kedua, faktor penghambat dalam Lapor Hendi terkait dengan teknologi. Berdasarkan hasil wawancara dengan P3M Kota Semarang, diketahui bahwa hambatan dalam teknologi berupa sering terjadinya sistem yang error. Hal ini karena banyaknya pengguna aplikasi Lapor Hendi ini sedangkan bandwith kapasitas system masih terbatas akibat sistem yang error akan menghambat dalam proses pelayanan aduan dan beberapa aduan yang tidak terarsip. Kendala selanjutnya ialah ketika sistem error pihak dinas akan memanggil pihak luar untuk memperbaiki sistem tersebut karena belum tersedianya sumber daya manusia (staff khusus) yang memiliki kapasitas untuk perbaikan sistem. Padahal akan lebih baik, yang memperbaiki sistem tersebut jika terjadi error ialah pihak P3M langsung, agar tidak penundaan waktu karena menunggu jasa perbaikan.

\section{PENUTUP}

\section{Kesimpulan}

Lapor Hendi adalah layanan pengaduan berbasis online untuk menyampaikan pengaduan, menyampaikan aspirasi dan berkomunikasi langsung dengan Pemkot Semarang. Hasil evaluasi Lapor Hendi ditemukan dalam penerapan sudah berjalan namun berjalan kurang optimal baik dari segi efektivitas, efisiensi, kecukupan, perataan, responsivitas dan ketepatan. Untuk itu diperlukan perbaikan dan pengembangan lebih lanjut agar dapat memberikan hasil yang lebih maksimal sesuai yang ditargetkan. Peneliti menyebutkan Lapor Hendi ini sebagai jembatan pengaduan yang setengah hati karena kurang maksimalnya pelaksaaan program ini.

\footnotetext{
${ }^{21}$ Krisdanti dan Rodhiyah (2014). Analisis Faktor-Faktor Yang Mempengaruhi Kinerja Ukm Pada Sektor Industri Pengolahan Makanan Di Kota Semarang.https://media.neliti.com/media/publications/190092ID-analisis-faktor-faktor-yang-mempengaruhi.pdf
} 
Hasil penelitian menemukan bahwa faktor penghambat pelaksanaan program ini adalah sumber daya manusia dan teknologi. Adanya hambatan administratif dan keterbatasan teknologi menjadi alasan kurang maksimalnya layanan Lapor Hendi.

\section{Rekomendasi}

1. Dibuthkan Standard Operating Procedure (SOP) sebagai turunan Perwal 34 tahun 2017 untuk memastikan tahapan, waktu, tanggapan/jawaban instansi, dan klasifikasi laporan pengaduan.

2. Sebagai bukti pengaduan telah diselesaikan perlu ada bukti, misalnya gambar.

3. Pemkot perlu mencantumkan kontak person yang bisa dihubungi untuk memfasilitasi masyarakat yang ingin bertanya tentang status pengaduan yang disampaikan

\section{DAFTAR PUSTAKA}

Adrian. 2017. Layanan Aspirasi dan dan Pengaduan Rakyat / Lapor Hendi Semarang. http://eprints.undip.ac.id/61809/3 diunduh tanggal 27 Oktober 2018

Ancok, Jamaludin. 2009. Komunikasi Publik. Yogyakarta: Gajah Mada Press

Bappeda Kota Semarang .2017.Menatap Semarang Jauh ke depan dalam Visi dan Misi Kota Semarang

Djamrut, D. E.2015. Inovasi Pelayanan Publik di Kecamatan Sungai Kunjang Kota Samarinda. eJournal Ilmu Pemerintahan Unmul, Vol. 3, No. 3 : 1472-1486.

Dunn, William N. 2005. Analisis Kebijakan Publik. Yogyakarta: Gajah Mada Press

Haryono, Yudhie.2008. Mental Kolonialisme. Jakarta: Nusantara Center

http://semarangkota.go.id/berita/read/pelayananpublikkotasemarangraihpredikatkepatuh antinggiombudsmanRI

http://p3msemarangkota.go.id.diakses 25 Oktober 2018

Joseph. 2015. Komunikasi Publik adalah kunci keberhasilan pelayanan publik. eJournal Ilmu Pemerintahan Unmul, Vol. 4, No. 3 : 1512-1526.

Krisdanti dan Rodhiyah (2014). Analisis Faktor-Faktor Yang Mempengaruhi Kinerja Ukm Pada Sektor Industri Pengolahan Makanan Di Kota Semarang.https://media.neliti.com/media/publications/190092-ID-analisis-faktorfaktor-yang-mempengaruhi.pdf

Komariah, D. S.2010. Metodologi Penelitian Kualitatif. Bandung: Alfabeta. 
Muzaki dan Manar 2017. Pengelolaan Lapor Hendi di Kota Semarang Tahun 2017, Kajian Sumber Daya Kebijakan. E-journal Undip.

Pattiro Semarang. 2017.Uji Pengaduan Pelayanan Pengolaaan Kota Semarang 2017.

ppid.semarangkota.go.id diakses pada 06 Maret 2018 Pukul 21.00 Wib

Sugiyono. 2009 Metode Penelitian Kuantitatif. Bandung: Alfabeta.

Undang-Undang Nomor 25 Tahun 2009 Tentang Pelayanan Publik

www.lapor.go.id diakses pada 14 September 2018 